Int. J. Electrochem. Sci., 11 (2016) 8245 - 8255

International Journal of

ELECTROCHEMICAL

SCIENCE

WWw.electrochemsci.org

\title{
Green Synthesis of Platinum Nanoparticles Using Quercus Glauca Extract and Its Electrochemical Oxidation of Hydrazine in Water Samples
}

\author{
R.Karthik ${ }^{1}$, R.Sasikumar ${ }^{1}$, Shen-Ming Chen ${ }^{1, *}$, M. Govindasamy ${ }^{1}$, J.Vinoth Kumar $^{2}$, V. Muthuraj ${ }^{2}$,
}

${ }^{1}$ Electroanalysis and Bioelectrochemistry Lab, Department of Chemical Engineering and Biotechnology, National Taipei University of Technology, No.1, Section 3, Chung-Hsiao East Road, Taipei 106, Taiwan (R.O.C).

${ }^{2}$ Department of Chemistry, VHNSN College, Virudhunagar -626001, Tamilnadu, India.

*E-mail: smchen78@ms15.hinet.net

doi: $10.20964 / 2016.10 .62$

Received: 25 July 2016 / Accepted: 28 August 2016 / Published: 6 September 2016

Facile, rapid and eco-friendly synthesis of platinum nanoparticles (Pt NPs) using aqueous leaves extract of Quercus glauca $(\mathrm{Qg})$ has been reported for first time to detection of environmental and human toxic hydrazine. The as-synthesized Pt NPs were characterized by spectroscopic and analytical techniques. The prepared Pt NPs were around spherical in shape and the size range from 5-15 nm. The electrocatalytic performance of hydrazine has been studied by CVs and amperometric techniques. Interestingly, the Pt NPs modified GCE shows a sharp peak at a very lower onset oxidation potential $-0.3 \mathrm{~V}$. The fabricated hydrazine sensor showed very lower detection limit, wide linear range, good sensitivity and excellent selectivity of $7 \mathrm{~nm}, 0.01$ to $283 \mu \mathrm{M}$, and $1.704 \mu \mathrm{A} / \mu \mathrm{M} / \mathrm{cm}^{2}$ respectively. The green synthesized Pt NPs modified GCE sensor was successfully used for the detection of hydrazine (Spiked) in various water samples.

Keywords: Quercus glauca, Eco-friendly, Platinum nanoparticles, Hydrazine

\section{FULL TEXT}

(C) 2016 The Authors. Published by ESG (www.electrochemsci.org). This article is an open access article distributed under the terms and conditions of the Creative Commons Attribution license (http://creativecommons.org/licenses/by/4.0/). 